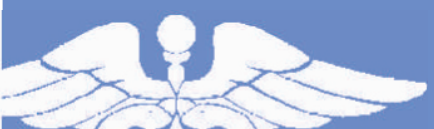

ISSN: 2782-7550 (Print) ISSN: 2782-7542 (Online)
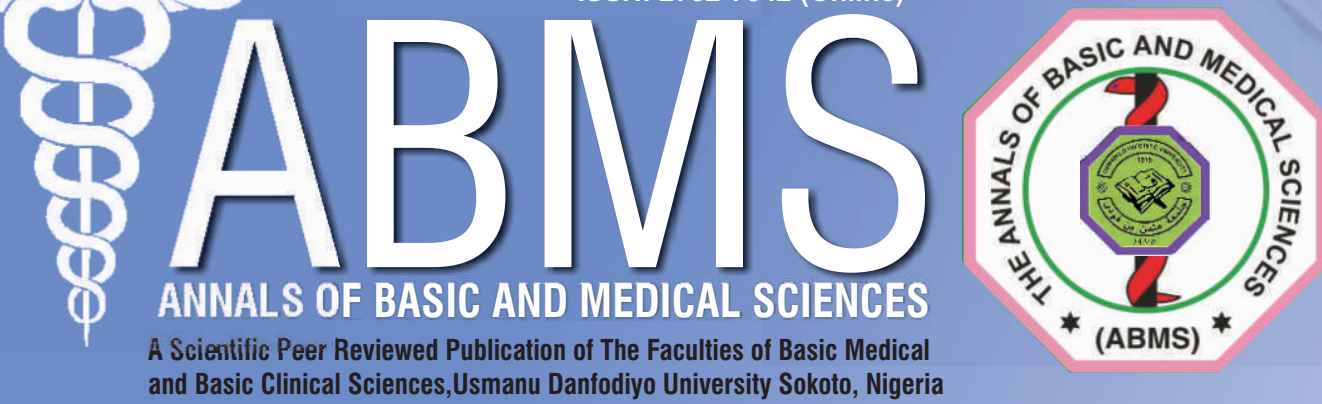

and Basic Clinical Sciences,Usmanu Danfodiyo University Sokoto, Nigeria
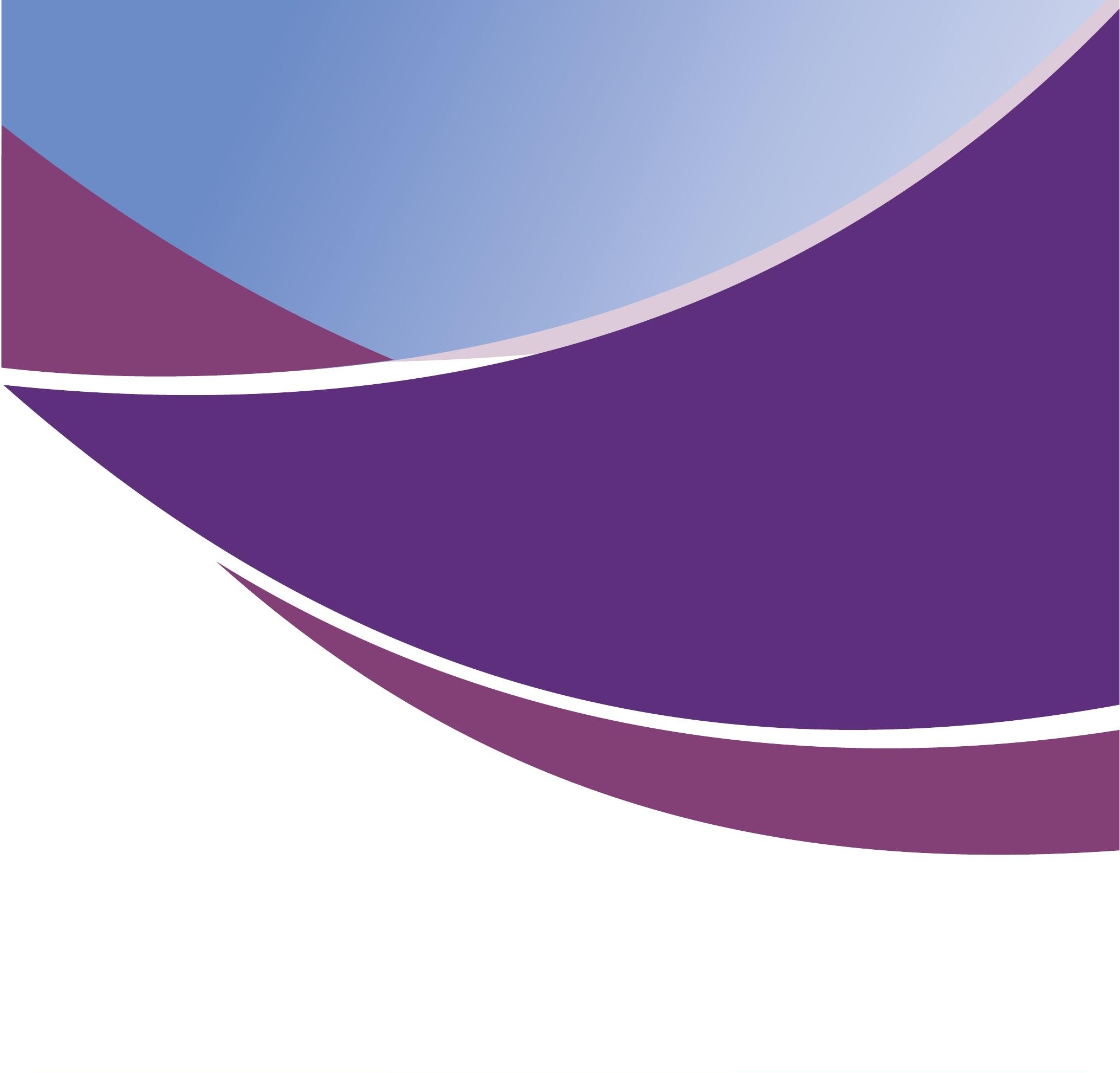


\title{
Relationship between Body Mass Index, waist-to-hip ratio and glycaemic control status of adult diabetics in Makurdi, Nigeria
}

Akwaras, A. Nndunno1, Abah Jonah O1, Omokhua Osarieme $E^{2}$, Atabo Amodu', Daniel D. Aondona1, Ochiefa N Mathew, Tor-Ayiin JK', Nwaeze Chukwuemeka', Swende L Terrumun', Eru Emmanuel ${ }^{3}$, Ibu John ${ }^{3}$.

${ }^{1}$ Department of Family Medicine, Federal Medical Centre, Makurdi, Benue State Nigeria.

${ }^{2}$ Department of Family Medicine, Benue State University Teaching Hospital, Benue State Nigeria. ${ }^{3}$ Department of Physiology. Benue State University, Benue State, Nigeria

\begin{abstract}
Background: Diabetes mellitus is a metabolic disorder that affects carbohydrate, protein and fat metabolism. Body mass index (BMI) and waist-to-hip ratio (WHR) are known anthropometric measurements used to assess body fat. Good glycaemic control among diabetics has been found to be difficult to achieve. Several factors including increased body fat have been found to affect glycaemic control.
\end{abstract}

Aim: This study aimed to assess the relationship between the anthropometric indices (BMI and WHR) and glycaemic control among adult diabetics attending the General Out-patient Clinic (GOPC) of Federal Medical Centre Makurdi (FMC) Makurdi.

Materials and methods: This was a cross-sectional study of 359 diabetic patients aged between 18 to 77 years selected by systematic sampling technique. Data was collected by interviewer-administered questionnaire. Clinical measurements undertaken included BMI, WHR and blood pressure. Fasting blood glucose assay was done for all respondents.

Results: The proportion of those with good glycaemic control was $58 \%$. The mean BMI was $27.49 \pm 4.20 \mathrm{~kg} / \mathrm{m}^{2}$ while $36.2 \%$ of the participants had normal BMI, $0.6 \%$ were underweight, $34.8 \%$ were overweight and $28.4 \%$ were obese. The mean WHR was $0.93 \pm 0.90 \mathrm{~cm}$ and $62.1 \%$ of the subjects had abnormal WHR. The respondents' $\mathrm{BMI}$ and WHR were significantly associated with glycaemic control.

Multiple logistic regression showed that, normal BMI ( $\mathrm{aOR}=3.46, \mathrm{Cl}=1.63-7.35, p=0.01)$ and normal waistto-hip ratio $(\mathrm{aOR}=2.56, \mathrm{Cl}=1.38-4.77, p=0.03)$, were independent predictors of good glycaemic control.

Conclusion: The study suggests that a significant proportion of the subjects had poor glycaemic control and were mostly overweight or obese. The study also confirms that BMI and WHR are associated with glycaemic control. Primary care physicians should therefore increase efforts at counseling type-2 diabetics on the importance of optimizing body weight.

Keywords: Anthropometry, Glycaemic Control, Diabetes, Makurdi

Corresponding author:

Dr. Akwaras, A. Nndunno, Department of Family Medicine Federal Medical Centre, Makurdi Benue State Nigeria. email- nndunnoakwaras@gmail.com Phone number 0806779761

\section{Introduction}

$\mathrm{D}$ iabetes mellitus is a common metabolic disorder worldwide (1). It has a profound influence on carbohydrate, lipid and protein metabolism (1). In 2017, 425 million people worldwide were estimated to be living with diabetes with $80 \%$ living in low and middle income countries (2) This figure is expected to increase to 629 million by 2045 (2). Nigeria has the highest number of people living with diabetes in the African continent and the prevalence of type 2 diabetes (T2DM) among Nigerian adults for 2017 was $2.4 \%$ (2). Anthropometric indices such as body mass index (BMI) and waist-to-hip ratio (WHR) have been recognized to have effect on health outcomes of patients with metabolic disorders $(3,4,5)$.

The World Health Organization (WHO) classifies BMI into underweight (less than $18.5 \mathrm{~kg} / \mathrm{m}^{2}$ ), normal weight ( 18.5 to $24.9 \mathrm{~kg} / \mathrm{m}^{2}$ ), overweight $\left(25\right.$ to $29.9 \mathrm{~kg} / \mathrm{m}^{2}$ ) and obese (over $\left.30 \mathrm{~kg} / \mathrm{m}^{2}\right)(6)$ Obesity is further classified into class I $\left(30-34.9 \mathrm{~kg} / \mathrm{m}^{2}\right)$, class II $\left(35-39.9 \mathrm{~kg} / \mathrm{m}^{2}\right)$ and class III (greater than $\left.40 \mathrm{~kg} / \mathrm{m}^{2}\right)(6)$. Some advantages and disadvantages of the use of BMI have been noted. An advantage is that, BMI appears significantly correlated with various metabolic and disease outcomes as it is a more direct measure of body fat $(4,7,8)$. It is also inexpensive and easy to measure $(4,7,8)$. One of its drawbacks is that, it does not take into consideration variation in physical characteristics such as truncal obesity. The BMI also fails to take into account loss of height through aging (4). The WHR is another simple technique for determining body fat distribution which takes into account the differences in body structure (6). Visceral adiposity is characterized by abdominal/truncal obesity of the android pattern, rather than the gynaecoid or pear-shaped pattern, which is more common in women and is characterized by adipose tissue storage mainly in the thighs and gluteal region (6). 
A WHR in men greater than 0.90 and greater than 0.85 in women causes increased risk for both cardiovascular disease and hypertension $(6,8)$. The WHR has been found to be more strongly related to visceral fat than to subcutaneous fat (6). However, WHR has limitations because it cannot distinguish between subcutaneous and visceral abdominal fat. There is substantial evidence of sex and age variation in WHR and some evidence for ethnic differences (6).

Good glycaemic control is a fasting blood glucose of $70-130 \mathrm{mg} / \mathrm{dL}(3.9-7.2 \mathrm{mmol} / \mathrm{L})(1)$. The results obtained from studies on glycaemic control reports good glycaemic control of $64 \%, 42.7 \%, 25.1 \%$ and $26 \%$ from Russia (9), China (10), Saudi Arabia (11) and Cameroun (12) respectively. In two Nigerian studies carried out in Ibadan (13) and Umuahia (14) reported good glycaemic control of $65.7 \%$ and $61.7 \%$ respectively. However, literature on the impact of BMI and WHR on glycaemic control are few. Some studies have found a relationship between anthropometric indices and glycaemic control (15, 16). In a Bulgarian study, a significant inverse correlation between glycated haemoglobin ( $\mathrm{HbA} 1 \mathrm{c})$ and $\mathrm{BMI}$ was found (15). Similar observation was reported by Alramadan and colleagues in Saudi Arabia (16) who attributed the findings to their lifestyle, diet and other specific factors in different nations.

Among many factors, urbanization is implicated as a factor fuelling the rise in T2DM $(8,17,18)$. Urbanization is associated with relocating to an urban area, adopting dietary habits which are high in carbohydrates and saturated fats, reduced physical activity, and more reliance on motorized transport $(8,17,18)$. The impact of such eating habit and sedentary lifestyles may impact on BMI and WHR which are measures of body fat. The impact of these changes in BMI and WHR on the prevalence and management outcome of T2DM are important aspects to be evaluated especially that poor glycaemic control has been associated with increased financial burden and complications (2).

\section{Materials and methods}

This was a cross-sectional analytical study involving 359 diabetic patients aged $18-77$ years. The study was conducted at the General Out-patient Clinic of Federal Medical Centre Makurdi and the duration of the study was three months. The minimum sample size required was calculated using the Leslie and Kish formula for single proportion (19).

When $10 \%$ of the minimum sample size (326) for anticipated non-response, incompletely filled data and missing questionnaires was added (32.6 approximated to 33), the sample size was 359 patients.

The participants were selected by systematic random sampling method after obtaining written consent. Ethical approval was obtained from the Ethical committee of Federal Medical Centre, Makurdi. All patients who presented or benefitted from health education on regular eye check, foot care, and nutrition and lifestyle modifi cation were included in the study. Those that were found to be hypertensive were commenced on antihypertensives. An interviewer-administered questionnaire was used. The questionnaires contained information on socio- demographic data and relevant history. The BMI, WHR and blood pressure were measured. Fasting blood glucose assay was recorded once as the patient presented for their routine check-up.

\section{Inclusion criteria}

1.Counseled adult diabetic patients aged 18 years and above.

2.Patients regular on their oral medications and presented for follow-up for at least three consecutive months prior to the time of the study.

3. Those who had received nutritional counselling and had been adherent to such dietary advice during the course of their management.

\section{Exclusion criteria}

1.Critically ill patients.

2.Pregnant patients.

Data collection, measured variables and instruments used

1.Questionnaire: The questionnaire was interviewer administered and consisted of three sections, A, B and C. The first section $(A)$ obtained information about the sociodemographic characteristics of the subjects including age, sex, marital status, highest level of education attained, occupation, ethnic group, religion and average monthly income.

The second section $(\mathrm{B})$ assessed relevant diabetes history of the patient which could serve as confounders such as family history of diabetes, duration of diagnosis of diabetes, duration of taking medication and number of medication(s) taken, current smoking status, alcohol ingestion and level of physical activity.

The last section $(C)$ of the questionnaire contained record of anthropometric indices (BMI and WHR), blood pressure and fasting blood glucose measurements.

\section{Measured variables}

1. Body weight: The weighing scale (ZT 120 Health Scale) was placed on a flat surface. Zero mark calibration was ensured before each measurement. Subjects were politely requested to remove their footwear and empty their pockets of accessories such as cell phones, keys and pocket diaries. The study subjects stood still at the centre of the scale's platform to distribute weight evenly to both feet. The weight was recorded with the resolution of the scale to the nearest 0.1 kilogram $(\mathrm{kg})$.

2. Height: The standing heights of study subjects were measured using a stadiometer (ZT 120 Health Scale). They were asked to remove their footwear and headgear or cap. The back of the head (occiput), buttocks, calves and heels was against the vertical board of the stadiometer. The investigator asked them to look straight so that the top of the external auditory meatus (ear canal) was at the same level with the inferior margin of the bony orbit (cheek bone). The head piece of the stadiometer was lowered so that the hair (if present) was pressed flat. Height was recorded to the resolution of the height rule of the nearest 0.1 centimetre $(\mathrm{cm})$. The average of two measurements was taken. 
3.Body Mass Index: The body mass index (BMI) was calculated using the formula:

$$
\mathrm{BMI}=\frac{\text { Weight }(\mathrm{Kg})}{\text { Height }^{2}\left(\mathrm{~m}^{2}\right)}
$$

The participants were classified on the basis of their $\mathrm{BMI}$ into underweight (BMI< 18.5), normal (BMI of 18.5 to $<25$ ), overweight (BMI of 25 to $<30$ ) and Obese $(\mathrm{BMI} \geq 30$ ).

4.Waist Circumference measurement: Waist circumference was measured using a measuring tape at the level midway between the lowest rib margin and iliac crest with the tape all around the body in horizontal position. The study subjects stood with their feet fairly close together (about $12-15 \mathrm{~cm}$ apart) so that their weight was equally distributed. They were asked to breathe normally and the reading of the measurement was taken at the end of gentle exhalation. This was to prevent subjects from contracting their abdominal muscles or from holding their breath. The tape was loose enough to allow the investigator to place one finger between the tape and subject's body. Measurements were recorded to the resolution of the measuring tape to the nearest $0.1 \mathrm{~cm}$. The average of two measurements was taken.

5. Hip Circumference measurement: Hip circumference was measured using a measuring tape. It was measured at the maximal circumference around the buttock posteriorly and the pubic symphysis anteriorly to the nearest $0.1 \mathrm{~cm}$. The average of two measurements was taken.

6. Waist-to-hip ratio: WHR $=$ Waist Circumference/Hip circumference (Normal is $\leq 0.90$ for males and $\leq 0.85$ for females). Waist-to-hip ratio of $>0.90$ for males and $>0.85$ for females was classified as abnormal.

7.Blood pressure measurement: The blood pressure was taken with Accoson ${ }^{(R)}$ mercury sphygmomanometer and a 3M Littmann ${ }^{(R)}$ stethoscope. Blood pressure was measured with the subject seated and relaxed for about 5 minutes, with back support, legs uncrossed and the arm supported at heart level. The cuff was applied to cover two third of the upper arm length. The stethoscope was placed gently over the brachial artery at its point of maximal pulsation at the cubital fossa and the cuff was then inflated rapidly to about $30 \mathrm{mmHg}$ above the palpated systolic pressure. The cuff was then deflated at a rate of $2-3 \mathrm{mmHg}$ per second to listen to the Korotkoff first and fifth sounds which corresponds to systolic and diastolic blood pressure respectively. The average of two blood pressure measurements taken at an interval of at least 2 minutes was used. The subjects were classified using the JNC7 report on the prevention, detection, evaluation and treatment of high blood pressure into normal $(<120 / 80 \mathrm{mmHg})$, pre-hypertensive $(120-$ $139 / 80-89 \mathrm{mmHg})$ and hypertensive $(\geq 140 / 90 \mathrm{mmHg})$.

8.Fasting blood glucose: This was measured at the side laboratory using glucometer (One touch ultra 2). Good glycaemic control was taken as FBG between 3.9 and $7.2 \mathrm{mmol} / \mathrm{L}(70-130 \mathrm{mg} / \mathrm{dL})$ according to the
American Diabetes Association guidelines for acceptable limits of glycaemic control. Those with FBG of < $7.2 \mathrm{mmol} / \mathrm{L}$ were classified as having good glycaemic control.

\section{Data analysis}

The data was analyzed using the Statistical Package for Social Sciences (SPSS) version 18. Qualitative variables were expressed as proportions while quantitative variables were expressed as mean and standard deviation. Chi-square was used to test for association between two categorical variables. Multiple logistic regression analysis was used to identify the independent predictors of glycaemic control. Independent variables entered into the multiple logistic regression model were those that were significant at $0.1 \%$ on bivariate analysis. Adjusted odds ratio and its $95 \%$ confidence interval were calculated. The level of significance was set at $p<0.05$.

\section{Results}

Socio-demographic characteristics of the respondents

Table 1 shows the respondents' socio-demographic characteristics. The age range of the respondents was $35-77$ years and the mean age was $56.05 \pm 10.32$ years. Respondents aged $55-64$ years $(n=131,36.5 \%)$ and $45-54$ years $(n=118,32.9 \%)$ made up slightly more than twothirds of the respondents. The age group with the least frequency was $75-84$ years $(n=17,4.7 \%)$.

There was an almost equal distribution of males (50.1\%) and females $(49.9 \%)$. Most of the respondents were married $(n=239,66.6 \%)$. Slightly more than four-fifths of the respondents had either secondary education $(n=113$, $31.5 \%)$ or tertiary education ( $n=182,50.7 \%)$. On occupation, the highest proportion were the unskilled $(n=100$, $27.9 \%)$, while skilled workers had the least frequency $(n=18$, $5 \%)$ Tiv was the most predominant tribe $(n=150,41$. $8 \%)$ and majority of the participants were Christians $(n=326,90.8 \%)$. Nearly half $(n=177,49.3 \%)$ of the total population earned between $\mathrm{A} 18,000$ and $\mathrm{A} 58,999$ monthly and the least proportion were those who earned less than N $18,000(n=49,13.6 \%)$.

Relevant history of diabetes and blood pressure status of the respondents.

Table 2 describes the relevant history of diabetes and blood pressure status of the study participants. More than half of the subjects had family history of diabetes $(n=195,54.3 \%)$. Slightly more than half of the respondents had been diagnosed with diabetes between one and five years before the study ( $n=187,52.1 \%)$, followed by those with 6-10 years of diagnosis $(n=107$, $29.8 \%$ ). The least proportion were those diagnosed for $<1$ year $(n=26,7.2 \%)$.

Nearly two-thirds of the respondents had been taking medications for between one and five years $(n=223$, $62.1 \%)$. The least proportion were those who had been taking medications for $>10$ years $(n=17,4.7 \%)$. Most were taking one type of medication $(n=220,61.3 \%)$. Only five persons $(1.4 \%)$ were taking three types of medications.

A vast majority of the respondents did not smoke ciga- 
Table 1. Socio-demographic characteristics of the respondents $(n=359)$

\begin{tabular}{|c|c|c|}
\hline $\begin{array}{l}\text { Sociedemographic } \\
\text { characteristics }\end{array}$ & Frequenc & Percent \\
\hline \multicolumn{3}{|l|}{ Age (in years) } \\
\hline $35-44$ & 46 & 12.8 \\
\hline $45-54$ & 118 & 32.9 \\
\hline $55-64$ & 131 & 36.5 \\
\hline $65-74$ & 47 & 13.1 \\
\hline \multirow{2}{*}{\multicolumn{3}{|c|}{$\begin{array}{l}\text { Mean (SD) }=56.05(10.3 \\
\text { Gender }\end{array}$}} \\
\hline & & \\
\hline Male & 180 & 50.1 \\
\hline \multirow{2}{*}{\multicolumn{3}{|c|}{ Marital status }} \\
\hline & & \\
\hline Single & 16 & 4.5 \\
\hline Married & 239 & 66.5 \\
\hline Separated & 24 & 6.7 \\
\hline Divorced & 2 & 0.6 \\
\hline Widowed & 69 & 19.2 \\
\hline \multirow{2}{*}{\multicolumn{3}{|c|}{ Level of education }} \\
\hline & & \\
\hline $\begin{array}{l}\text { None } \\
\text { Primary }\end{array}$ & $\begin{array}{r}9 \\
55\end{array}$ & $\begin{array}{r}2.5 \\
15.3\end{array}$ \\
\hline $\begin{array}{l}\text { Primary } \\
\text { Secondary }\end{array}$ & 113 & 31.5 \\
\hline \multirow{2}{*}{\multicolumn{3}{|c|}{ occupation }} \\
\hline & & \\
\hline Professional & 23 & 6.4 \\
\hline Clerical & 66 & 18.4 \\
\hline A rtisan & 31 & 8.6 \\
\hline S killed & 18 & 5.0 \\
\hline Sem is killed & 31 & 8.6 \\
\hline Unskilled & 100 & 27.9 \\
\hline Unemployed & 90 & 25.1 \\
\hline \multicolumn{3}{|l|}{ Ethnicity } \\
\hline $\begin{array}{l}\text { Tiv } \\
\text { Idom a }\end{array}$ & $\begin{array}{l}150 \\
106\end{array}$ & $\begin{array}{l}47.8 \\
29.5\end{array}$ \\
\hline lgede & 32 & 8.9 \\
\hline Others & 71 & 19.8 \\
\hline \multicolumn{3}{|l|}{ Religion } \\
\hline Christianity & 326 & 90.8 \\
\hline Islam & 32 & 8.9 \\
\hline Traditional & 1 & 0.3 \\
\hline \multicolumn{3}{|l|}{$\begin{array}{l}\text { Average monthly inco } \\
\text { in NairaNX }\end{array}$} \\
\hline Less than 18,000 & 49 & 13.6 \\
\hline $18,00-(\$ 8,999$ & 177 & 49.4 \\
\hline $59,00-99,999$ & 77 & 21.4 \\
\hline 100,000 and above & 56 & 15.6 \\
\hline
\end{tabular}

rette $(n=309,86.1 \%)$. More than half of the participants did not ingest alcohol $(n=220,61.3 \%)$. Those who ingested alcohol significantly made up the least proportion $(n=112,19.4 \%)$. Adequate physical activity was found in slightly above a third of the respondents $(n=124$, $34.5 \%$ ). Majority of respondents had normal blood press ure $(n=309,86.1 \%)$.

Table 2. Relevant history of diabetes and blood pressure status of the respondents

\begin{tabular}{|c|c|c|}
\hline Variables & Frequenc & Percent \\
\hline \multicolumn{3}{|c|}{ Family history of diabetes (years) } \\
\hline Yes & 195 & 54.3 \\
\hline No & 1 & 45.7 \\
\hline \multicolumn{3}{|c|}{ Duration of diabetes diagnosis (yeal } \\
\hline$<1$ & 26 & 7.2 \\
\hline $1-5$ & 187 & 52.1 \\
\hline $6-10$ & 107 & 29.8 \\
\hline$>10$ & 39 & 10.9 \\
\hline \multicolumn{3}{|c|}{ Duration on medication(s) in years } \\
\hline$<1$ & 54 & 15.0 \\
\hline $1-5$ & 223 & 62.1 \\
\hline 6-10 0 & 65 & 18.1 \\
\hline$>10$ & 17 & 4.7 \\
\hline \multicolumn{3}{|c|}{ Number of medication(s) } \\
\hline One medication & 220 & 61.3 \\
\hline Two medications & 134 & 37.3 \\
\hline Three medications & 5 & 1.4 \\
\hline \multicolumn{3}{|c|}{ Currentsmoking status } \\
\hline Yes & 50 & 13.9 \\
\hline No & 309 & 86.1 \\
\hline \multicolumn{3}{|c|}{ Category of alcoholintake } \\
\hline $\begin{array}{l}\text { No intake } \\
\text { Significant }\end{array}$ & $\begin{array}{r}220 \\
27\end{array}$ & $\begin{array}{r}61.3 \\
7.5\end{array}$ \\
\hline Not significant & 112 & 31.2 \\
\hline \multicolumn{3}{|c|}{ Category of physical activity } \\
\hline Adequate & 124 & 34.5 \\
\hline Inadequate & 235 & 65.5 \\
\hline \multicolumn{3}{|c|}{ Blood pressure status } \\
\hline Normal & 309 & 86.1 \\
\hline Hypertensive & 50 & 13.9 \\
\hline
\end{tabular}

Body mass index (BMI) and waist-to-hip ratio (WHR) of the respondents

Table 3 shows the body mass index (BMI) and waistto-hip ratio (WHR) of the respondents. The mean \pm standard deviation of the BMI was $27.49 \pm 4.20 \mathrm{~kg} / \mathrm{m}^{2}$, with $130(36.2 \%)$ respondents having normal BMI and closely followed by overweight ( $n=125,34.8 \%)$ while 102 $(28.4 \%)$ were obese. The mean \pm standard deviation of the WHR was $(0.93 \pm 0.90)$. A higher proportion of respondents had abnormal WHR $(n=223,62.1 \%)$.

Table 3. BMI, WHR and blood pressure status of the respondents

\begin{tabular}{lll}
\hline Variables & Frequency & Percent \\
\hline Body mass index (BMI) & & \\
kg/m² & & 0.6 \\
Underweight $(<18.5)$ & 2 & 36.2 \\
Normal $(18.54 .9)$ & 130 & 34.8 \\
Overweight $(259.9)$ & 125 & 28.4 \\
Obese ( $\geq 30)$ & 102 & \\
Mean (SD)=27.49 (4.20) & & 37.9 \\
Waist/hip ratio (WHR) & & 62.1 \\
Normal & 136 & \\
Abnormal & 223 & \\
Mean (SD)= $0.93(\mathbf{0 . 9 0})$ & &
\end{tabular}

Glycaemic control status of the respondents Figure 1 shows that $208(58 \%)$ of the participants had good glycaemic control. The remaining 151 (42\%) had poor glycaemic control.

Fasting blood glucose (mg/dl)

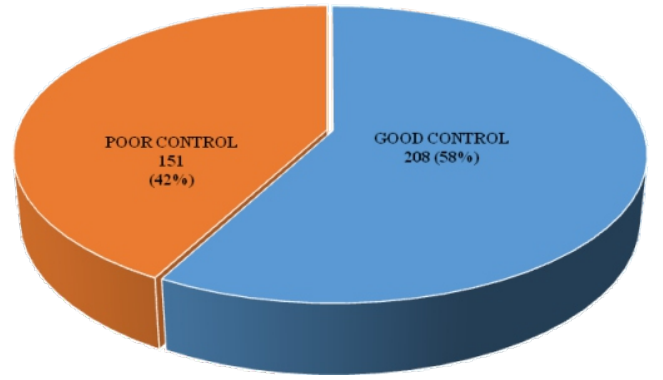

Figure 1. A pie chart showing the glycaemic control status of the respondents.

Mean fasting blood glucose (FBG) levels between those with good glycaemic control and those with poor glycaemic control

As shown in Table 4, the mean fasting blood glucose level was significantly lower in those with good glycaemic control compared to those with poor glycaemic control (5.90 $\pm 0.77 \mathrm{mmol} / \mathrm{L}$ vs $9.05 \pm 1.54 \mathrm{mmol} / \mathrm{L}, \mathrm{p}<0.01)$.

Table 4. Comparison of means of FBG of good Vs poor glycaemic control

\begin{tabular}{llllll}
\hline Variable & $\begin{array}{l}\text { Mean } \\
\text { FBG }\end{array}$ & Std & T & Df & $\begin{array}{l}\text { p- } \\
\text { value }\end{array}$ \\
\hline Good control & 5.90 & 0.77 & & & \\
Poor control & 9.05 & 1.54 & -25.44 & 357 & $<0.01$ \\
\hline
\end{tabular}




\section{Relationship between BMI, WHR and glycaemic control}

Table 5 shows the association between respondents' BMI, WHR and glycaemic control. Respondents with normal BMI had the highest prevalence of good glycaemic control $(73.8 \%, \mathrm{n}=96)$ compared to overweight $(67.2 \%, n=84)$ and obese patients $(27.5 \%, n=28)$. The prevalence of good glycaemic control was higher in those with normal WHR compared to those with abnormal WHR (75.7\%, n=103 Vs 47.1\%, n=105). There was a statistically significant association between BMI and glycaemic control as well as between WHR and glycaemic control $(p<0.01)$.

Table 5: Relationship between BMI, WHR and glycaemic control

\begin{tabular}{|c|c|c|c|c|c|}
\hline \multirow{2}{*}{ Variables } & \multicolumn{5}{|c|}{ Fasting Blood Glucose (mg/dl) } \\
\hline & $\begin{array}{c}\text { Good Control } \\
n=208 \\
n(\%) \\
\end{array}$ & $\begin{array}{c}\text { Poor Control } \\
n=151 \\
n(\%)\end{array}$ & $\begin{array}{l}\text { Test } \\
\text { Statistics }\end{array}$ & df & p-value \\
\hline $\begin{array}{l}\text { Body mass index } \\
(\mathrm{BMI}) \mathrm{kg} / \mathrm{m}^{2}+\end{array}$ & & & $x^{2}=59.56$ & 3 & $<0.01^{\star}$ \\
\hline Underweight $(<18.5)$ & $0(0.0)$ & $2(1.3)$ & & & \\
\hline Normal (18.5-24.9) & $96(73.8)$ & $34(26.2)$ & & & \\
\hline Overweight (25-29.9) & $84(67.2)$ & $41(27.2)$ & & & \\
\hline Obese $(\geq 30)$ & $28(27.5)$ & $74(72.5)$ & & & \\
\hline $\begin{array}{l}\text { Waist-hip-ratio } \\
\text { (WHR) }\end{array}$ & & & $x^{2}=28.45$ & 1 & $<0.01^{*}$ \\
\hline Normal & $103(75.7)$ & $33(24.3)$ & & & \\
\hline Abnormal & $105(47.1)$ & $118(52.9)$ & & & \\
\hline
\end{tabular}

*Statistically significant

Relationship between socio-demographic variables and glycaemic control

Table 6 shows the bivariate analysis of socio-demographic characteristics and glycaemic control. The proportion of good glycaemic control was highest in the $45-54$ years age group $(68.6 \%, n=81)$ and lowest in the $65-74$ years age group $(36.2 \%, n=17) p=0.003)$. The pre valence of good glycaemic control was higher in the male respondents $(62.2 \%, n=112)$ compared to the females $(53.6 \%, n=96)$, however, this was not statistically significant $(p=0.099)$. The prevalence of good glycaemic control was highest among respondents that were cohabiting $(77.8 \%, n=7)$ and lowest among those that were divorced $(50.0 \%, n=1)$. However, this was also not statistically significant $(p=0.281)$.

Those with tertiary education had the highest prevalence of good glycaemic control $(68.7 \%, n=125)$, while those with the least proportion of good glycaemic control had primary education $(45.5 \%, \mathrm{n}=25)(p<0.01)$. Respondents with the highest prevalence of good glycaemic control were the professionals while the least prevalence was among the unemployed $(35.6 \%, n=32)(p<0.01)$. Idoma respondents had the highest prevalence of good glycaemic control $(68.9 \%, n=73)$ while the least prevalence was seen among the Igede tribe $(43.8 \%, n=14)$ $(p=0.033)$. Christian respondents had the highest prevalence of good glycaemic control $(60.1 \%, n=196)$. Islam practicing respondents had a good glycaemic control prevalence of $(37.5 \%, n=12)$. The only respondent who practiced traditional religion had poor glycaemic control $(p=0.011)$.

The prevalence of good glycaemic control increased as average monthly income increased. It was lowest in

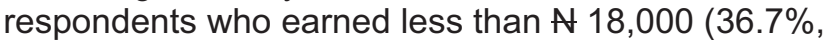
$n=18$ ) and highest in respondents who earned $\mathbb{N} 100,000$
Table 6. Association between socio-demographic variables and glycaemic control

\begin{tabular}{|c|c|c|c|c|c|}
\hline \multirow[b]{2}{*}{$\begin{array}{l}\text { Sociodemographic } \\
\text { charaderistics }\end{array}$} & \multicolumn{5}{|c|}{ Fasting blood glucose } \\
\hline & $\begin{array}{c}\text { Good } \\
\text { control } \\
n=208 \\
n(\%)\end{array}$ & $\begin{array}{c}\text { Poor control } \\
n=151 \\
n(\%)\end{array}$ & $\begin{array}{c}\text { Test } \\
\text { statistics }\end{array}$ & Df & $\begin{array}{c}\text { P- } \\
\text { value }\end{array}$ \\
\hline Age (in years)+ & & & $x^{2}=15.83$ & 4 & $0.003^{*}$ \\
\hline $35-44$ & $29(63.0)$ & $17(37.0)$ & & & \\
\hline $45-54$ & $81(68.6)$ & $37(31.4)$ & & & \\
\hline $55-64$ & $72(55.0)$ & $59(45.0)$ & & & \\
\hline $65-74$ & $17(36.2)$ & $30(63.8)$ & & & \\
\hline $75-84$ & $9(52.9)$ & $8(47.1)$ & & & \\
\hline Gendert & & & $x^{2}=2.72$ & 1 & 0.099 \\
\hline Male & $112(62.2)$ & $68(37.8)$ & & & \\
\hline Female & $96(53.6)$ & $83(46.4)$ & & & \\
\hline Marital status & & & $\begin{array}{r}\text { Fisher's } \\
\text { exact }=6.06\end{array}$ & 5 & 0.281 \\
\hline Single & $11(68.8)$ & $5(31.3)$ & & & \\
\hline Married & $134(56.1)$ & $105(43.9)$ & & & \\
\hline Separated & $18(75.0)$ & $6(25.0)$ & & & \\
\hline Divorced & $1(50.0)$ & $1(50.0)$ & & & \\
\hline Widowed & $37(53.6)$ & $32(46.4)$ & & & \\
\hline Co-habiting & $7(77.8)$ & $2(22.2)$ & & & \\
\hline Level of educationt & & & $x^{2}=17.81$ & 3 & $<0.0 *$ \\
\hline None & $5(55.6)$ & $4(44.4)$ & & & \\
\hline Primary & $25(45.5)$ & $30(54.5)$ & & & \\
\hline Secondary & $53(46.9)$ & $60(53.1)$ & & & \\
\hline Tertiary & $125(68.7)$ & $57(31.3)$ & & & \\
\hline Occupation+ & & & $x^{2}=28.84$ & 6 & $<0.0 \pi^{*}$ \\
\hline Professional & $18(78.3)$ & $5(21.7)$ & & & \\
\hline Clerical & $45(68.2)$ & $21(31.8)$ & & & \\
\hline Artisan & $21(67.7)$ & $10(32.3)$ & & & \\
\hline Skilled & $10(55.6)$ & $8(44.4)$ & & & \\
\hline Semiskilled & $22(71.0)$ & $9(29.0)$ & & & \\
\hline Unskilled & $60(60.0)$ & $40(40.0)$ & & & \\
\hline Unemployed & $32(35.6)$ & $58(64.4)$ & & & \\
\hline Ethnicity+ & & & $x^{2}=8.76$ & 3 & $0.033^{*}$ \\
\hline Tiv & $82(54.7)$ & $68(45.3)$ & & & \\
\hline Idoma & $73(68.9)$ & $33(31.1)$ & & & \\
\hline Igede & $14(43.8)$ & $18(56.3)$ & & & \\
\hline Others* & $39(54.9)$ & $32(45.1)$ & & & \\
\hline Religion+ & & & $\begin{array}{r}\text { Fisher's } \\
\text { exact }=7.31\end{array}$ & 2 & $0.01 \%$ \\
\hline Christianity & $196(60.1)$ & $130(39.9)$ & & & \\
\hline Islam & $12(37.5)$ & $20(62.5)$ & & & \\
\hline Traditional & $0(0.0)$ & $1(100.0)$ & & & \\
\hline Average monthly & & & $x^{2}=11.96$ & 3 & 0.008 \\
\hline Less than 18,000 & $18(36.7)$ & $31(63.3)$ & & & \\
\hline $18,00058,999$ & $104(58.8)$ & $73(41.2)$ & & & \\
\hline $59,00099,999$ & $48(62.3)$ & $29(37.7)$ & & & \\
\hline 100,000 and above & $38(67.9)$ & $18(32.1)$ & & & \\
\hline
\end{tabular}

and above $(67.9 \%, \mathrm{n}=38(p=0.008)$.

Logistic regression analysis of independent factors predicting glycaemic control.

A logistic regression analysis shown in Table 7 was done to determine the independent predictors of glycaemic control amongst the study participants. Independent variables that were eligible to be entered into the logistic regression model were those that were significant at $0.1 \%$ on bivariate analysis. They included age, gender, level of education, occupation, ethnicity, religion and average monthly income (Nigerian Naira). BMI and WHR were also eligible.

Compared to those aged $35-54$ years, those aged 75-84 years were nearly three times more likely to have good glycaemic control $(\mathrm{aOR}=2.92, \mathrm{Cl}=0.44-19.54$, $p=0.27$ ). Those aged $45-54$ years and $55-64$ years also had higher odds of achieving good glycaemic control $(\mathrm{aOR}=1.49, \mathrm{Cl}=0.50-4.46, \mathrm{p}=0.47)$ and $(\mathrm{aOR}=1.12$, $\mathrm{Cl}=0.34-3.63, \mathrm{p}=0.86$ ) respectively. The least odds of having good glycaemic control was among those aged $65-74$ years $(\mathrm{aOR}=0.93, \mathrm{Cl}=0.21-4.00, \mathrm{p}=0.92)$. Age was not an independent predictor of glycaemic control.

Men were less likely to have good glycaemic control compared to females $(\mathrm{aOR}=0.73, \mathrm{Cl}=0.41-1.32, \mathrm{p}=0.30)$. Those with tertiary education were more likely to achieve good glycaemic control $(\mathrm{aOR}=1.14, \mathrm{Cl}=0.21-6.14$, $p=0.88$ ) compared to others with lower educational levels. Gender and education were not independent predictors 
of glycaemic control.

The odds of having good glycaemic control was slightly more than three times higher among those whose occupation was in the professional cadre $(\mathrm{aOR}=3.17, \mathrm{Cl}=0.56-17.80, \mathrm{p}=0.19)$ compared to the The Idoma respondents were more likely to achieve glycaemic control $(\mathrm{aOR}=1.55, \mathrm{Cl}=0.66-3.60, \mathrm{p}=0.31)$. Those who were Christians (reference group) were more likely to have good glycaemic control $(p=0.55)$. The odds of achieving good glycaemic control decreased as the average monthly income of the respondent increased. Occupation, ethnicity, religion, and average monthly income were not independent predictors of glycaemic control. With reference to obese respondents those with normal BMI were more likely to have good glycaemic control and it was statistically significant $(\mathrm{aOR}=3.46, \mathrm{Cl}=$ $1.63-7.35, p=0.01$ ). Those with normal WHR were about two and a half times more likely to achieve good glycaemic control compared to those with abnormal WHR $(\mathrm{aOR}=2.56, \mathrm{Cl}=1.38-4.77, p=0.03)$.

Table 7: Logistic regression model of independent variables predicting glycaemic control

\begin{tabular}{|c|c|c|c|}
\hline Variables & $\begin{array}{c}\text { Adjusted } \\
\text { odds ratio } \\
\text { (aOR) }\end{array}$ & $\begin{array}{c}95 \% \\
\text { confidence } \\
\text { interval } \\
\text { (CI) }\end{array}$ & p-value \\
\hline \multicolumn{4}{|l|}{ Age (in years) } \\
\hline $35-44^{*}$ & 1.00 & & \\
\hline $45-54$ & 1.49 & $0.50-4.45$ & 0.47 \\
\hline $55-64$ & 1.12 & $0.34-3.63$ & 0.86 \\
\hline $65-74$ & 0.93 & $0.21-4.00$ & 0.92 \\
\hline $75-84$ & 2.92 & $0.44-19.57$ & 0.27 \\
\hline \multicolumn{4}{|l|}{ Gender } \\
\hline Male & 0.73 & $0.41-1.32$ & 0.30 \\
\hline Female $^{*}$ & 1.00 & & \\
\hline \multicolumn{4}{|l|}{ Level of Education* } \\
\hline None* & 1.00 & & \\
\hline Primary & 0.63 & $0.12-3.35$ & 0.59 \\
\hline Secondary & 0.51 & $0.10-2.57$ & 0.41 \\
\hline Tertiary & 1.14 & $0.21-6.14$ & 0.88 \\
\hline \multicolumn{4}{|l|}{ Occupation } \\
\hline Professional & 3.17 & $0.56-17.80$ & \\
\hline Clerical & 1.64 & $0.44-6.14$ & 0.46 \\
\hline Artisan & 1.36 & $0.35-5.21$ & 0.66 \\
\hline Skilled & 0.54 & $0.13-2.34$ & 0.41 \\
\hline Semiskilled & 2.06 & $0.60-7.16$ & 0.25 \\
\hline Unskilled & 1.20 & $0.47-3.07$ & 0.71 \\
\hline Unemployed* & 1.00 & & \\
\hline \multicolumn{4}{|l|}{ Ethnicity } \\
\hline Tiv & 0.65 & $0.29-1.46$ & 0.30 \\
\hline Idoma & 1.55 & $0.66-3.60$ & 0.31 \\
\hline Igede & 0.57 & $0.187-1.71$ & 0.31 \\
\hline Others* & 1.00 & & 0.48 \\
\hline \multicolumn{4}{|l|}{ Religion } \\
\hline Christianity* & 1.00 & & \\
\hline Islam & 0.57 & $0.20-1.58$ & 0.28 \\
\hline Traditional & 0.00 & & \\
\hline \multicolumn{4}{|l|}{$\begin{array}{l}\text { Average Monthly } \\
\text { Income (N) }\end{array}$} \\
\hline Less than $18,000^{*}$ & 1.00 & & \\
\hline $18,000-58,999$ & 0.91 & $0.33-2.49$ & 0.85 \\
\hline $59,000-99,999$ & 0.82 & $0.25-2.63$ & 0.73 \\
\hline \multicolumn{4}{|l|}{100,000 and } \\
\hline above & 0.52 & $0.13-2.11$ & 0.36 \\
\hline \multicolumn{4}{|l|}{$\begin{array}{l}\text { Body mass index } \\
\text { (BMI) } \mathrm{kg} / \mathrm{m}\end{array}$} \\
\hline Underweight $(<18 . !$ & 0.00 & & 0.99 \\
\hline Normal (18-34.9) & 3.46 & $1.63-7.35$ & $0.01^{+}$ \\
\hline $\begin{array}{l}\text { Overweight ( } 25 \\
29.9)\end{array}$ & 1.38 & $0.70-2.73$ & 0.07 \\
\hline $\begin{array}{l}\text { Obese }(\geq 30)^{*} \\
\text { Waist/hip ratio } \\
\text { (WHR) }\end{array}$ & 1.00 & & \\
\hline Normal & 2.56 & $1.38-4.77$ & 0.03 \\
\hline Abnormal* & 1.00 & & \\
\hline
\end{tabular}

\section{Discussion}

An analysis of the glycaemic control among the study participants indicated that $58 \%$ of the participants had good glycaemic control. This is lower than $86.1 \%$ obtained from a nationwide stratified multistage study in the United States (21). The lower proportion of good glycaemic control obtained in this study may be due to lower socioeconomic power obtained in our environment which can make it difficult for patients to afford their dietary demands. The higher proportion of good glycaemic control obtained in a developed nation like the United States may be due to better health facilities and high economic power. Conversely in another developed nation, Denmark, Rovgi and colleagues reported lower prevalence of good glycaemic control of $33 \%$ among 1081 participants (22). The lower glycaemic control may be due to the fact that it was a cross sectional study with a response rate of $54 \%(22)$. Furthermore, the facility used for the Denmark study was a specialist diabetes clinic that gave care to severely ill and those with complications which could have contributed to the lower prevalence of good glycaemic control. Alzaheb et al., in a cross-sectional study of 423 patients at a tertiary diabetic clinic in Saudi Arabia found that the prevalence of good glycaemic control was $25.1 \%$ (11). Alzaheb et al., also found that greater risk of poor glycaemic control was seen among patients living in urban areas, those who were overweight or obese and those who did not undertake sufficient exercise (11). Similarly, in this study respondents who had abnormal BMI and WHR were more likely to have poor glycaemic control.

The prevalence of glycaemic control of $58 \%$ obtained in this study was higher than $45 \%$ obtained by Ufuoma and colleagues in a cross-sectional study aimed at assessing the level of glyceamic control and its determinants among 200 T2DM patients attending a secondary hospital in Warri, Nigeria (23). BMI showed a statistically significant association with glycaemic control $(p<0.01)$ mirroring the report of some authors in Saudi Arabia(16), Hawaii (24), Nigeria (23), Bulgaria (15), India (25) and Malaysia (26) but was inconsistent with some other studies in Turkey (27), Romania (28) and United States (29). The reason for this finding in this study is unclear. However, the possible mechanism of the association of poor glycaemic control with increased BMI may be aggravation of insulin resistance due to increased fat mass and visceral adiposity, which affects insulin sensitivity and causes insulin resistance (30)

WHR also showed a statistically significant association with glycaemic control $(p<0.01)$ which is in consonance with a study by Alramadan in Saudi Arabia (16). The reason for this finding may be similar to that of BMI since WHR is also a measure of body fat.

In this study, BMI and WHR were independent predictors of glycaemic control following multiple regression analysis. With reference to obese respondents those with normal BMI were more likely to have good glycaemic control. This is in agreement with findings by Alzaheb and colleagues in Saudi Arabia (11).

Those with normal WHR were about two and a half times more likely to achieve good glycaemic control compared 
to those with elevated WHR $(\mathrm{aOR}=2.56, \mathrm{Cl}=1.38-4.77$, $p=0.03$ ). The likelihood of having good glycaemic control when the WHR is normal has also been reported in Saudi Arabia (16). The findings on BMI and WHR can be attributed to increased insulin resistance when body fat increases (30).

Conclusion: Normal BMI and WHR have been identified in this study to be independent predictors of good glycaemic control. The respondents' BMI and WHR, showed statistically significant association with glycaemic control. This implies that counseling diabetic patients on the need for weight reduction may be useful in their management.

\section{Acknowledgement}

The management of Federal Medical Centre, Makurdi is appreciated for the use of its facility for this study.

\section{Conflict of interest: None}

\section{References:}

1. American Diabetes Association. Standards of medical care in diabetes. Diabetes Care 2017; 35: 519-520.

2. International Diabetes Federation: IDF Diabetes Atlas, $8^{\text {th }}$ edn Brussels, Belgium. 2017. Available at http://www.idf.org/ diabetesatlas. Accessed 2/10/ 2018

3. Dahiru T, Aliyu AA, Shehu A U. A review of population-based studies on diabetes mellitus in Nigeria. Sub-Saharan Afr J Med. 2016; 3: $59-64$

4. Chinedu SN, Ogulana OO, Azuh DE, Iweala EE, Afolabi IS, Uhuegbu $\mathrm{CC}$ et al. Correlation between body mass index and waist circum ference in Nigerian adults: implication as indicators of health status. J Public Health Res. 2013; 2(2): e16 doi 10.4081/jphr.2013.e16.

5. Raimi TH, Odewabi AO, Odusan O, Fasanmade O. Correlation of anthropometric indices and age with fasting plasma glucose among inhabitants of Ogun State, south west, Nigeria. Br J Med Med Res. 2015; 19(5): 1-11.

6. Prakash S, Shikiri K, Gary T. Waist circumference and waist hip ratio:report of a WHO expert consultation. Geneva. 8-11 Decem ber 2008. Available at world health organization-2011-apps.WHO. int. Accessed on 8/11/2018

7. Wang Y. Use of Percentiles and Z-Scores in Anthropometry. Hand book of Anthropometry. New York: Springer. 2012; 29.

8. Ekpeyong CE, Udokang NE, Akpan EE, Sampson TK. Double bur den, non communicable diseases and risk factors evaluation in sub Saharan Africa: the Nigerian experience. Eur J Sustain Dev. 2012; 1(2): 249-270.

9. Dedov II, Kalashnikova M, Belousov D, Rafalskiy V, Kalashnikov $\mathrm{VY}, \mathrm{Kolbin}$ AS. Assessing routine healthcare pattern for type 2 diabetes mellitus in Russia: the results of pharmacoepidemiological study (FORSIGHT-DM2). Diabetes. 2016; 19(6): 443.

10.Jailin L, Kaushik C, Miao X, Yanshu C, Fangfang H, Jianping C. Glycaemic control in type 2 diabetes patients and its predictors: a retrospective database study at a tertiary care diabetic centre in Ningbo, China. BMJ open. 2017; 8(3): 19697.

11.Alzaheb RA, Altemani AH. Prevalence and determinants of poor glycaemic control among adults with type 2 diabetes mellitus in Saudi Arabia. Diabetes Metab Syndr Obes. 2018; 11: 15-21.

12. Camara A, Balde NM, Sobngwi-Tabekou J, Kengne AP, Diallo MM, Tchatchoua AP et al. Poor glycaemic control in type 2 diabetes in the South of the Sahara: the issue of limited access to an HBA1c test. Diabetes Res Clin Pract. 2015; 108(1): 187-192.
13.Adisa R, Fakeye TO, Fasanmade A. Medication adherence among ambulatory patient with type 2 diabetes in a tertiary health care setting in South western Nigeria. Pharm Pract. 2011; 9:72-81.

14.Pascal IG, Ofeodu JN, Uchenna NP, Nkwa AA, Uchamma GU Blood glucose and medication adherence among adult type 2 diabetic Nigerians attending a primary care clinic in under-resourced environment of Eastern Nigeria. N Am J Med Sci. 2012; 4(7): 310-315.

15.Baltadjiev A, Vladevas A, Tineshev S, Andreenko E. Correlations between some anthropometric parameters, the lipid profile and glycated haemoglobin in Bulgarian women with type 2 DM. Int $J$ Pharm Sci Invent. 2016; 5(3): 31-34.

16.Alramadan MJ, Magliano DJ, Almigbal TH, Batais MA, Afroz A Almarahan HJ. Glycaemic control for people with type 2 diabetes mellitus in Saudi Arabia- an urgent need for a review of manage ment plan. BMC Endocr Disord. 2018; 18: 62.

17.Etukumana EA, Puepet FH, Obadofin MO. Prevalence of diabetes mellitus among adults in rural northcentral Nigeria. High L Med Res J. 2013; 13(2): 98-100.

18.Ige OK, Owoaje ET, Adebiyioa. Non communicable disease and risky behaviour in an urban university community. Afr Health Sci. 2013; 13: 62-67.

19.Araoye MO. Research Methodology with statistics for Health and Social Sciences. Nathedex Publishers, Ilorin. 2004; 115 - 122.

20.Adebisi SA, Oghagbon EK, Akande TM, Olarinoye JK. Glycated haemoglobin and glycaemic control of diabetes in Ilorin. Niger $\mathrm{J}$ Clin Pract. 2010; 12: 87-91.

21.Ali MK, Bullard KM, Imperatore G, Barker L, Gregg EW. Charac teristics associated with poor glycemic control among adults with self-reported diagnosed diabetes-National Health and Nutrition Examination Survey, United States, 2007-2010. Morb Mortal Wkly Rep. 2012; 61(2): 32-37.

22.Rovgi S, Tapger I, Almadal TP. Patient factors and glycaemic control - associations and explanatory power. Diabetes Med. 2012; 29 (10): $382-389$

23. Ufouma C, Godwin YD, Kester AD, Ngozi JC. Determinants of glycaemic control among persons with type 2 diabetes mellitus in Niger Delta. Sahel Med J. 2016; 19: 190-195.

24.Juarez DT, Sentell T, Tokumaru S, Goo R, Davis JW, Mau MM Factors associated with poor glycaemic control or wide glycaemic variability among diabetes patient in Hawaii, 2006-2009. Prev Chronic Disease. 2012; 9: 120065

25.Bobby SK, Latha N. Impact of body mass index on glycaemic control in type 2 diabetes mellitus. J Den Med Sci. 2018; 17(11): 32-35.

26. Reidpath DD, Soyiri I, Jahan NK, Mohan D, Ahmad B, Ahmad MP et al. Poor glycaemic control and its metabolic and demographic risk factors in a Malaysian community- based study. Int J Public Health. 2018; 63: 193-202.

27.Kayar Y, Ilhan A, Kayar NB, Unver N, Coban G, Ekini I et al. Rela tionship between poor glycaemic control and risk factors, life style and complications. Biomed Res. 2017; 28(4): 1581-1586.

28. Mut-Vitcu G, Hudrea I, Mosteoru S, Gaia L, Gaita D. Body mass index and glycaemic control in patients with diabetes mellitus: a case control study. Rom J Diabetes Nutr Metab Dis. 2017; 24(2) 119-125.

29.Nguyen N, Nguyen X, Lane J, Wang P. Relationship between obesity and diabetes in a US adult population: findings from the National Health and Nutrition Examination Survey, 1999-2006. Obes Surg. 2011:21(3):351-355.

30.Frier BM, Truswell AS, Shepherd J, Looy AD, Jung R. Diabetes mellitus, and nutritional and metabolic disorders. In; Nicki RC Brian RW, Stuart R, Stanley D editors. Davidson's principles and practice of Medicine. $20^{\text {th }}$ Ed. New York: Churchill Livingstone/ Elsevier; 2006. 472-478. 